\title{
The Dynamics of Religious Moderation in Bangka Island
}

\author{
Ahsanul Khalikin ${ }^{1}$, Reslawati ${ }^{2}$ \\ \{akhalikin72@gmail.com¹, mutiara2810cinta@gmail.com² ${ }^{2}$,
}

Center for Research and Development of Community Guidance and Religious Services

Research and Development and Training Agency, The Ministry of Religious Affairs (MoRA)

the Republic of Indonesia ${ }^{1,2}$

\begin{abstract}
Issues on fundamentalism, radicalism, extremism and terrorism have continued to spread for the last two decades, along with various cases that have encouraged them. Indonesia, which is known for its hospitality, mutual cooperation, kinship, and friendship, seems to have changed. In the historical trajectories recorded in inscriptions, cultural practices, and intellectual documents, Indonesia has indeed been considered as a tolerant or moderate state. It is interesting to see if this truth still exists or has been written off by new values. To portray such truth, this research is accordingly conducted in Bangka Island. With a qualitative method, the research data on how religious moderation in this area is actually maintained or has even changed over time according to the needs of the times are obtained.
\end{abstract}

Keywords: moderation, religion, culture, local wisdom

\section{INTRODUCTION}

The dynamics of moderation is something which is moving, resilient, solid, shifting, and progressive. This is what the research expects to find in Bangka Islands of Indonesia described in this article. The question is how society, government, and other stakeholders interact, communicate and associate one another, particularly on religious issues. Basically, Bangka Island is a unique example of this dynamic of moderation. With about 1.5 million populations, it's said to be the miniature of Indonesia as it represents various elements in the country, both in terms of religions and ethnic groups (1). In addition, the dynamics of the religious relationships shows some uniqueness. Although the island is basically in harmony, conflicts also arise, even more than once.

Such characteristics of moderateness, compromise, and rejection to violence and crime in moderate Islam can be found in the Malay cultural value system of Bangka Belitung. The moderate Islamic characters have dominated and colored the Malay cultural value system of Bangka Belitung. The character of moderate Islam has influenced the development of the Bangka Belitung's Malay culture, particularly in fusing Shari'a precepts with customary law. Moderate characters have allowed the Bangka Belitung people to accept different values. In the Bangka Belitung's Malay cultural beliefs, faith, worship, and morality are aligned with the local customs, which must be upheld and preserved (2).

Interestingly, the people of Bangka Island have traditions and values that keep the conflicts under control, not to spread over. In fact, in some cases, the local traditions are reproduced en masse to build and foster harmony among its people (3). In addition, religious moments are also used as a means of uniting racial and religious differences. Jargons fostering harmony are even made and displayed to be contemplated and institutionalized in their heart (3). However, cultural development with advances in technology and political system is feared to gradually replace or change traditions, characters, and media for their meetings. It is also likely to lead to frictions and provoke greater conflicts. As the miniature of Indonesia, Bangka 
Island portrays and illustrates how Indonesia dynamizes the moderation needed to unite its people who are increasingly vulnerable to conflict. The paper tries to uncover the resiliency of Bangka people to sustain harmonious society.

\section{RESEARCH METHOD}

This article is resulted from a qualitative research. To gather data, the authors utilize some techniques such as in-depth interview, observation and literature review. The authors interviewed some influential figures in Bangka Island, such as academician, public servant as well as Islamic clerics.

\section{RESULT AND DISCUSSION}

\section{The History of Bangka Island}

Bangka Island is an integral part of Belitung Island as Indonesia's $31^{\text {st }}$ province known as Bangka Belitung. During the British colonization, it was once renamed the Duke of York's Island by Sir G. Elliot Earl of Minto, the British Governor General in India. With an area of $11,693.54 \mathrm{~km}^{2}$, Bangka is bordered by the South China Sea to the north, the Gaspar Strait, Karimata Strait and Belitung Island to the east, the Java Sea to the south, and the Bangka Strait and the East Coast of Sumatra Island to the west (4). Now, it has five regions: Bangka, West Bangka, Central Bangka, South Bangka and Pangkalpinang (1).

Several terms are used as the origin of the word "Bangka", such as Wangka, which means tin mining exploration and Bangka that means living around swamp areas as well as asmall huts (5). Bangka has also meant boat which derivates from the word wangkang (Chinese). The boats are thought to be built in the coastal areas of West Kalimantan, located in the north of the Java Sea, Bangka and Belitung. There are at least four different ethnic groups; the People of the Land, the People of the Sea, the Chinese and the Malays. Before known as Malays, the indigenous people of Bangka were called "Urang Lom" $(5,6)$.

Urang Lom refers to the people of the Land and the people of the Sea. They are known to be very reliable in Malayan waters, catching sea cucumbers and seaweeds $(6,7)$. The People of the Land or also called the People of the Hill are people whose primary activity is farming rice and glutinous rice or pulut (5). Lom people applies a special rule in the social and cultural systems. The systems originally come from their ancestral traditions and survive in the midst of changing times (6). They practice as a means of contemplating and reflecting on themselves. The contemplation ritual, for example, becomes their way to communicate with nature and their ancestors. Rituals, curses, abstinence, spells and incantations in the cosmology of the Lom people are understood as a manifestation of social principles (6). Rituals always go hand in hand with the recitation of mantras, incantations and prayers in every customary ceremony carried out by the Lom people. In the process, the Nujuh Jerami and Nambek Kubur rituals, for example, show the existence of sacred elements that plays an important role in relations among human and between human and nature. Bangka Malays refers to two theories regarding their migration; first, they are from an area in Indonesia and then migrate through the Peninsula and cross over the nearest islands, Kalimantan, Sumatra, and the Philippines; second, they come from South China and cross over Kalimantan and the Philippines.

According to Bangka historians, the Malays are identical with Islam as they must be Muslims. For this reason, if the People of the Land or those of the Sea convert to Islam, they are often referred to as Malays because of their religion. Muslims in Bangka are Malay people. They speak Malay and have Malay customs. Those who are not Malay, but live in Bangka are Chinese - also called Lom people, because they are not circumcised or are not Muslim (5). A 
literature source shows that around the $17^{\text {th }}$ Century, there were large migrations from mainland China into Bangka Island. They came to open tin mining both as owners and also workers, and brought the technology to process the tin (8).

Those different ethnic groups built an inter-ethnic assimilation, then the term Tong Ngin Fan Ngin Jit Jong emerged, which was first familiarized by the former Governor of Bangka Belitung Province, Hudarni Rani, during her time of service (2002-2007). The meaning of the motto is the Malays and Chinese are equal. Due to its popularity, the term has continued to spread so widely that no separation among them. They are united with Bhineka Tunggal Ika (Unity in Diversity), living in harmony despite their differences.

2. Islamization of Bangka

Teungku Sayyid Deqy (9) gives more details about how Islam entered Bangka. It came in several phases as follow:

a. In the $10^{\text {th }}$ to $12^{\text {th }}$ century, the Islamization in Bangka came around the Pejam, Mount Pelawan, Mount Cundong, Air Abik, Tuing, and Mapur areas and was brought by Shaykh Syarif Abdul Rasyeed from Hadhramaut, Yemen. He was known as Akek Antak.

b. In the $13^{\text {th }}$ to $14^{\text {th }}$ century, the Islamization in Bangka was brought by Shaykh Sulaiman. He mostly introduced Islam in the Maras and Kota Kapur areas.

c. In the $15^{\text {th }}$ century, the Islamization in Bangka was carried out by the Demak war fleet that stopped over in the Tengkalat-Pejam and Mount Pelawan areas in Bangka and was on its way to Malacca to storm over the Portuguese.

d. In the $15^{\text {th }}$ to $16^{\text {th }}$ century, the Islamization in Bangka was brought by Sheikh Cermin Jati and his descendants. It includes the Pejam-Tengkalat, Mount Palawan, Mount Cundong, Simpang Tiga, Air Abik, Mapur, Maras, Tiang Tarah, Bangkakota, and Permis areas.

e. At the end of the $16^{\text {th }}$ to $19^{\text {th }}$ century, the Islamization in Bangka varied with the arrival of Panglima Tuan Syarah, Sultan Johor, Raja Alam Harimau Garang, Ratu Bagus from the Banten Sultanate, and the Palembang Sultanate in several periods. It has been introduced by Banjar scholars including Syeikh Siddiq, Gusti Kacil (Gusti Abdul Madjid), and KH Khotamar Rasyid recently (5).

The influence of Islam is present in various aspects, ranging from holiday celebrations, wedding procession, and memorials to other aspects of life. It can simply be seen from the way of dressing up, covering the essential or intimate parts of body (aurat).

\section{Today's Bangka Island}

As the center of the Bangka Belitung Islands Province, Bangka Island was once part of South Sumatra, then became a separate province, along with Banten and Gorontalo in 2000. The Bangka Belitung Islands Province was established based on the Law No. 27/2000 on the Establishment of the Bangka Belitung Islands Province on November 21, 2000. It consists of Bangka Regency, Belitung Regency and Pangkalpinang City. In 2003, the province was expanded with 4 additional regencies; West Bangka, Central Bangka, South Bangka and East Belitung. In short, the Bangka Belitung Islands Province is a regional division of South Sumatra Province. 
As per September 2019, the data by the Regional Office of the Ministry of Religious Affairs in Bangka Belitung Province shows the population of Bangka Belitung with the following details:

\begin{tabular}{|c|c|c|c|c|c|c|c|c|}
\hline \multirow[t]{2}{*}{ No } & \multirow[t]{2}{*}{ Regency/City } & \multicolumn{6}{|c|}{ Estimated Number of Religious Adherents } & \multirow[b]{2}{*}{$\begin{array}{r}\text { Estimated } \\
\text { population }\end{array}$} \\
\hline & & Islam & Christianity & Catholic & Hinduism & Buddhis & Confucianism & \\
\hline 1. & $\begin{array}{l}\text { Pangkal Pinang } \\
\text { City }\end{array}$ & 208.574 & 10.750 & 9.502 & 81 & 19.651 & 10.002 & 258.560 \\
\hline 2. & Bangka Regency & 328.989 & 12.352 & 3.537 & 13 & 43.178 & 24.100 & 412.269 \\
\hline 3. & $\begin{array}{l}\text { Central Bangka } \\
\text { Regency }\end{array}$ & 196.243 & 1.995 & 1.375 & 47 & 10.684 & 6.493 & 216.837 \\
\hline 4. & $\begin{array}{ll}\text { South } & \text { Bangka } \\
\text { Regency } & \end{array}$ & 232.945 & 1.150 & 1.070 & 328 & 4.053 & 6.516 & 246.062 \\
\hline 5. & $\begin{array}{l}\text { West Bangka } \\
\text { Regency }\end{array}$ & 222.434 & 2.299 & 732 & 22 & 15.332 & 602 & 18.987 \\
\hline 6. & Belitung Regency & 207.424 & 2.867 & 1.165 & 1.213 & 18.605 & 218 & 231.492 \\
\hline 7. & $\begin{array}{l}\text { East Belitung } \\
\text { Regency }\end{array}$ & 142.475 & 1.540 & 495 & 11 & 11.211 & 272 & 156.004 \\
\hline & Total & 1.539 .084 & 32.953 & 17.976 & 1.715 & 122.714 & 48.203 & 1.762 .645 \\
\hline & Percentage (\%) & 87,3 & 1,9 & 1,0 & 0,1 & 7,0 & 2,7 & \\
\hline
\end{tabular}

\begin{tabular}{|c|c|c|c|c|c|c|c|c|c|c|}
\hline No & Regency/City & \multicolumn{2}{|l|}{ Islam } & $\begin{array}{l}\begin{array}{l}\text { Christia } \\
\text { nity }\end{array} \\
\text { Church }\end{array}$ & $\begin{array}{l}\text { Catholic } \\
\text { Church }\end{array}$ & $\begin{array}{l}\text { Hinduism } \\
\text { Temple }\end{array}$ & \multicolumn{2}{|c|}{ Buddhis } & \multicolumn{2}{|c|}{ Confucianism } \\
\hline 1. & $\begin{array}{l}\text { Pangkal Pinang } \\
\text { City }\end{array}$ & 89 & 97 & 32 & 3 & 10 & 15 & 51 & 40 & 1 \\
\hline 2. & Bangka Regency & 175 & 230 & 58 & 6 & 9 & 22 & 60 & 79 & 2 \\
\hline 3. & $\begin{array}{l}\text { Central Bangka } \\
\text { Regency }\end{array}$ & 111 & 143 & 20 & 10 & 7 & 19 & 30 & 4 & 1 \\
\hline 5. & $\begin{array}{l}\text { West Bangka } \\
\text { Regency }\end{array}$ & 158 & 199 & 15 & 5 & 2 & 2 & 15 & 25 & 0 \\
\hline 6. & Belitung Regency & 135 & 111 & 13 & 1 & 6 & 17 & 35 & 12 & 2 \\
\hline 7. & $\begin{array}{l}\text { East Belitung } \\
\text { Regency }\end{array}$ & 173 & 37 & 11 & 3 & 4 & 23 & 26 & 16 & 2 \\
\hline & Total & 1016 & 892 & 177 & 30 & 46 & 116 & 244 & 223 & 10 \\
\hline
\end{tabular}

In the Meantime, The Number of Houses of Worship Built in All Cities and Regencies is as

Follows:

4. The Recent Religious Intolerance in Bangka Island

According to the latest data of the regional office of the Ministry of Religious Affairs in Bangka Belitung Province, 6 incidents of religious intolerance have been occurred since 2007, as illustrated in the following points:

a) The Conflict with Ahmadiyya Religious Group

This conflict has happened twice, the first of which was on January 8, 2007 in Srimenanti Village, Sungailiat District, Bangka Induk Regency. The activity of this religious group led by Jamaluddin Feeli brought negative reaction from various mass organizations in 
Bangka. In the end, a discussion was conducted between Ahmadiyya representatives and community leaders, the Head of Village, the Head of Environment, the Sungailiat Police Chief, the Head of Religious Affairs of Sungailiat, the Bangka Police, the Indonesian Ulema Council of Bangka, Muhammadiyah Representatives, and NU Representatives.

This discussion has generated the following agreements:

- The Ahmadiyya members are not allowed to carry out their activities

- They are not allowed to perform Friday prayer at home and use the Sri Menanti as the center of meeting to introduce the Ahmadiyya teachings

- The Ahmadiyya Religious Group is given the opportunity to introduce the Ahmadiyya teachings in areas that have not adopted a religion

The second conflict occurred on September 3, 2010. The People of Bangka and mass organizations demanded the local government of Bangka Regency to take a serious action because they didn't seem to be firm against the Ahmadiyya Religious Group. Their demands include the followings:

- Disbanding and banning all activities conducted by Ahmadiyya Religious Group

- Seizing all assets belonging to the Ahmadiyya Religious Group

- Returning Syarif Hidayatullah, the local head of Ahmadiyya, to his area of origin and prohibiting him from staying and living in Bangka Regency

- Requesting the law enforcement officials to guarantee that Ahmadiyya activities will not recur in Bangka Regency

- From these four demands, two points are finally decided:

- The Ahmadiyya Religious Group and all its activities in the Sri Meranti Village and its surroundings are disbanded.

- Ahmadiyya representatives receive compensation for their assets from the Local Government of Bangka Regency. Therefore, all assets in terms of land and buildings owned by the Ahmadiyya are controlled by the Local Government

b) The Establishment of Catholic Religious High Schools

On April 11, 2012, the establishment of Catholic Religious High Schools in Mangkol

Village, Central Bangka Regency, was rejected by the Nur Kartini mosque management in Mangkol Village, even though it had attached 588 signatures from the surrounding communities. The local government of Bangka itself did not issue an agreement because it had not fulfilled the requirements referring to the Law No. 55/2007 on Permits to Establish Religious Institutions, including:

- $\quad$ The permit from the Regional Office of the Ministry of Religious Affairs of the Bangka Belitung Islands is in Air Mesu Village

- The permit from the village was issued by the Head of Village whose terms of office has expired

- The permit issued by the Village Consultative Body was under pressure

- The diocese has never held any socialization on the establishment of the school to the public in general

- The establishment of an educational institution must have a principle permit from the Ministry of Religious Affairs located in Pangkalpinang City

Due to the incomplete requirements, the Regional Leadership Coordination Forum conducted a review of the establishment of seminary or religious schools on April 16, 2012. 
Finally, the Regional Representative Council of Indonesia-Indonesian Youth Mosque Communication Agency in Central Bangka Regency issued a letter of disapproval addressed to the Regent of Central Bangka on 26 April 2012. Such decision caused the Diocese of Pangkalpinang to establish a seminary school in Pangkalpinang City in the school complex areas and Bhakti Wara Hospital.

c) The Prohibition of Jami'atul Islamiyah Activities

The people of Jelutung II Village, Simpang Rimba District, South Bangka Regency, were uneasy and worried about the presence of Jami'atul Islamiyah which was considered to have caused disunity in the community. This is triggered by several things including:

- The different number of raka'at in tarawih prayer

- Conducting the Eid prayer on their own at Nurul Huda Mushalla (prayer room)

- The Zakat Fitrah (charity) paid by Jamiyatul Islamiyah followers was not fully distributed to nearby mustahiqs (those who are entitled to receive zakat), but brought to Palembang by the Jamiyatul Islamiyah professor, on KH Ahmad Apandi

In response to this case, the Head of Religious Office Affairs of Simpang Rimba, the Head of Jelutung II Village, the Secretary of Simpang Rimba District, the Head of Police and Nahdliyin Professional Entrepreneurs Association, the Village Secretary, community leaders, religious leaders, and the Chairperson of Jamiyatul Islamiyah (Ibnu Katsir) held a meeting on October 10, 2012. The results of the meeting are as follow:

- Religious activities on behalf of Jamiyatul Islamiyah in Jelutung II Village are stopped

- Inviting a religious teacher to conduct religious teachings at Nurul Huda Musholla in Jelutung II Village is prohibited

- The Eid and Tarawih prayer activities are held at Jami' mosque in Jelutung Village

- The zakat fitrah distribution is coordinated with the Amil Zakat (Zakat Orginizer) in Jelutung II Village

d) A Muslim Graveyard Has a Crossbar

The people in Air Mesu Village, Central Bangka Regency, were in shock after a grave digger discovered a crossbar and Bible which were deliberately placed on a Muslim's grave on August 17, 2011. Therefore, the village officials and the police chief clarified and confirm the case to clear the air On August 19, 2011.

e) The Construction of a Church in Kace Village, Mendo Barat, Bangka Regency

The people in Kace Village, Mendo Barat District, held a protest concerning the construction of a church. They were worried that it would affect them in some ways. The construction was deemed to not comply with the Joint Decree No. 9/2006 and No. 8/2006, but it was not clear on which part. Finally, the Head of the Mendo Barat district, the representatives of the Ministry of Religious Affairs of Bangka Regency and the representatives of the Inter-Religious Harmony Forum held a discussion with the church officials. It was then decided that the construction of the church was stopped as it did not get the approval from the people.

f) The Reading of Amsal (Proverbs) at Bumi Asih Hotel, Pangkalpinang city

Such incident occurred on September 18, 2006, when all employees of Bumi Asih Hotel, both Muslim and non-Muslim, were required to read the Proverbs by the management. This caused protests and discomfort. To that end, a meeting was held at the Regional Office of the Ministry of Religious Affairs on September 21, 2006 in Bangka Belitung Province. This 
meeting was attended by hotel employees, hotel manager and staff, Islamic Organizations, Himpunan Mahasiswa Isam (HMI or Islamic Student Union), Forum Kerukunan Umat Beragama (FKUB, or the Inter-Religious Harmony Forum of Province and the Inter-Religious Harmony Forum) of Pangkal Pinang City, the Head Unit of Bangka Belitung Regional Police, the Head of Islamic Affairs and Hajj Implementation at the Regional Office of the Ministry of Religious Affairs. The meeting has finally come to the following agreement:

- $\quad$ The reading of proverbs for Muslim is not required

- $\quad$ An apology from the hotel management is announced through the mass

media

- $\quad$ The hotel management Decree is submitted to the leadership in Jakarta

- A mushalla (prayer room) is made available at Hotel Bumi Asih

Apart from the aforementioned incidents which are collected based on interviews and data searches in the mass media, both printed and online data, there are two other incidents of intolerance that have not been mentioned as follow:

g) A Young Man Makes Fun of the Verses in Qur'an

In April 2019, a young man and his friends mocked one another on social media. $\mathrm{He}$ then made a video ridiculing the reading of surah Adh-Dhuha and adhaan. Suddenly, the video, which was initially uploaded on Facebook, spread everywhere, causing criticism from many parties. This incident was finally handled by the police.

h) Gunawan Tjen's Post on Facebook (The Chairman of Chamber of Commerce and Industry, Pangkalpinang)

In August 2019, the online media was in shock by the news that a prospective soldier of French descent was allegedly involved in radicalism. This has caused various reactions from the communities, including the people of Bangka Belitung, one of whom is Gunawan Tjen, the Chairman of Chamber of Commerce and Industry, Pangkalpinang. He questioned and criticized the Indonesian Army for not carefully examining and assessing their prospective soldiers and posted it on Facebook. He included Islamic symbols in his posting. This caused bad reactions and provoked the Muslim in Bangka. Many disagreed with his post. In the end, he apologized to the Muslim communities and the case was closed.

5. The Dynamics of Moderation In Bangka Island

a. The Motto of Each Region

There are many values and events showing the moderation side of the people of Bangka. It can symbolically be seen from the motto of each regency/city. The motto shows the philosophy of life in the areas. As commonly known, Bangka Belitung province itself has a motto called sarumpun sabalai. Sarumpun, for example, is interpreted as one origin or one citizen although they come from different ethnic backgrounds. In the meantime, sabalai means one house or one place to live. Therefore, this motto emphasizes that although they come from various ethnic groups, the population of Bangka Belitung all live in one house which must be guarded together.

The motto of the regencies/cities in Bangka Belitung Island is equally impressive. The following points illustrate the motto of each regency/city, especially Bangka Island:

- Sepintu Sedulang is the motto of Bangka Regency. It means one house, one tray. This refers to the nganggung tradition. In this tradition, each person prepares trays of food and shares them equally and they eat together. It shows the culture of sharing with one another.

- Sejiran Setason is the Motto of West Bangka Regency. It implies this regency has citizens whose behaviors are based on kinship and togetherness. 
- Junjung Besaoh is the motto of South Bangka Regency which literally means lift together, endure together. This shows the people in this regency uphold the spirit of mutual cooperation

- Selawang Segantang is the motto of Central Bangka Regency. The meaning of this motto is no different from other areas in Bangka. The means one door, one measuring instrument. The one door, for example, points out that the people of Central Bangka are open to good and constructive things. Meanwhile, gantang symbolizes the nature of mutual help and togetherness.

- Pangkal Kemenangan is the motto of Pangkalpinang city. This means it is the center of victory for the people of Bangka.

In general, the motto of each regency/city to emphasizes one thing in common, the people of Bangka are open to outsiders with new things and warmly accept them as long as they bring good things and improvement. Internally, they always build togetherness, accept differences, and prioritize mutual cooperation.

b. Sambut Sepintu Sedulang Dance

This is a welcoming dance for exalted guests. It is said to be a traditional dance that has deeply rooted as part of procession welcoming government officials and private guests who come to visit Bangka. It reflects the customs of the Bangka people who are friendly, polite, cheerful and happy, sincere and open to anyone, especially special guests who come to visit (10).

c. Adjoining Houses of Worship

There is a symbol of the closeness between Islam and Confucianism that has occurred since hundreds of years ago in Muntok, West Bangka Regency. Kong Fuk Miau Temple and Jami Mosque are two iconic buildings from Kampung Tanjung, Muntok District, that were built in the $18^{\text {th }}$ century. The harmony that exists between the Malays and Chinese has been built since long ago. Drs. Elvian, a member of Regional Representative Council in Bangka claims the meeting between Muslim Malays and Confucian Chinese has long happened and they have respected one another (11).

During the construction of a mosque, for example, not only Muslim who come to contribute, but many non-Muslim are there to support it, in terms of giving donation or financing and working on it. This is what the adjoining mosque and temple in Muntok really portrays. The mosque was built in mutual help between Muslims and non-Muslims. The time range between the construction of the temple and that of the mosque is very long, about around 80 years. Interestingly, some of the building materials for the mosque were donated from the temple, one of which is the poles that prop Jami' Mosque.

The researcher took his time to visit Tanjung Bunga Village, Bukit Intan district, Pangkal Pinang City. According to the information he got, there are various houses of worship from different religions. The information is true and he captured the moments. He saw several houses of worship that have been built magnificently. Interestingly, the houses of worship adjoin. There are several houses of worship built and used for performing religious activities, including pagodas, monasteries and temples.

d. Local Government Policies

Several regional regulations have been established to support various local traditions that can unite the people. One of the regulations is the one issued by the Governor of Bangka Belitung Island No. 41/2018 on the Establishment of the Malay Customary Institution in Bangka Belitung Islands Province. It mentions several important things to note (12) as follow:

First, the institution is considerably established to promote culture, maintain diversity, and organize a mechanism that can involve the people in the development of 
Culture. Second, the Malay Customary Institution is assigned to manage and solve various life issues by referring to the customs and customary laws of the people of Bangka Belitung Islands (Kartika, 2019). Based on these two points, it is very clear how local traditions play a role in resolving several conflicts that have occurred.

Further, the policies at the regency/city level also show a continuity of perspectives with the ones made by the provincial government; in the way they become local wisdom to unite the people. One of the regulations issued by the Regent of Bangka is the regulation No. 4 tz/2017 on the Preservation and Development of Customs and Socio-Cultural Values for the People of Bangka Regency.

Article 1 mentions the list of cultures that is protected and preserved. The cultures include Nganggung, Besaoh, Rebo Kasan, Pantun, Barzanji, and Ngeruah. Nganggung, for example, is the culture of carrying a complete meal on a pan covered by a food cover during religious celebrations (the detail of this culture is described in the next section). Besaoh is an activity of mutual help which is carried out among the villagers in turn. It is like arisan in terms of forestry/logging and other activities. Both nganggung and besaoh are actually media for the people to mingle with one another, regardless of their racial and religious backgrounds. For them, the cultures are not policies. They practice them in real life. In addition, Malay Pantun of Bangka is one of the cultural products that remain alive on the island of Bangka (one of the islands in the Province of Bangka Belitung Island).

1. The Tradition of Moderation in Local Cultures

Besides the aforementioned cultures, the people of Bangka Island have many moments of meeting among different ethnic and religious backgrounds as illustrated in the following points:

\section{a. Nganggung}

Nganggung is the culture of carrying a complete meal on a pan covered by a food cover during religious celebrations. The meal usually consists of rice, side dishes, fruits, and various cakes. In the meantime, the pan is a tray which is made of brass and has a round shape (3).

Basically, nganggung is a cultural tradition of the people of Bangka. This tradition is occasionally carried out to celebrate big holidays, Eid celebration, wedding ceremony, and welcoming guests of honor, among others. Basically, the nganggung tradition is a manifestation of the spirit of mutual help among the people. It aims at strengthening the relationship among the people in order to create harmony and peace (3).

The word nganggung itself comes from the word anggung which means to lift. People who take part in it usually lift their pan over their right shoulder. They then walk hand in hand to enter the mosque or village hall. The pans are placed in a long line. Those who come sit facing one another other. After the committee gives them some sign, they open the pans and eat together. Besides eating together, they can interact and exchange ideas through this tradition (3).

One pan usually contains various kinds of food. One famous food menu in Bangka Island is lepah kuning. This yellow food tastes spicy and sour. The distinctive aroma of belacan and Toboali shrimp paste make this type of food more delicious. Through the nganggung tradition, the people maintain and strengthen their kinship and relationship. This is because this tradition is a form of mutual help and community togetherness in overcoming problems together.

During the nganggung activity, all the villages in Bangka Island are very crowded and lively. The indigenous people generally stop their daily activities or routines. This 
tradition is usually carried out in langgar, surau or mosque on Friday (Suparta, 2017). During the celebration of Islamic holidays, besides Eid al-Fitr and Eid al-Adha, the people celebrate nganggung enthusiastically and with happiness. Through this tradition, the social dynamics and openness of the indigenous people of Bangka to people outside the village who come to visit are very visible. They greet and invite those who visit their village to stop by their house and serve them with the dishes they have provided (13).

The habit of mutual-help among the people of Bangka is very strong and is seen from various aspects of community life, ranging from activities with greater intensity to their daily routines. One form of the mutual help is building public facilities including mosques, customary halls, bathing places, cemeteries, and road construction, religious celebrations and occasions related to the life cycle, such as aqiqah (the sacrifice of an animal on the occasion of a child's birth), circumcision, Qur'an recitation, weddings, and memorials. In carrying out these mutual-help activities, the people always involve the nganggung tradition (13).

Almost all regions in Bangka are said to be familiar with nganggung tradition and practice it. Only the occasions or celebrations involving the tradition are different. In largescale celebrations, it is somewhat different. The West Bangka, for example, is famous with a Ketupat War, South Bangka with the $1^{\text {st }}$ of Muharram, Central Bangka with the celebration of mauled (the Celebration of the Prophet's Birthday), and Bangka Induk with Rebo Kasan or Ruahan respectively. Essentially, this tradition is a gathering place for the people (13).

On the other hand, nganggung itself is intended to promote solidarity in the way people come together, which may have started to fade. Its increasing development on Islamic holidays and memorials is a form of public concern to support the grieving families. In addition, it is also a form of mutual help among the people that needs to be preserved. It is said to be a means or media to gather them in one place in order to achieve their personality. The more often the nganggung tradition is held, the better their personality will be. For this reason, it is carried out and maintained by the people of Bangka.

b. The $1^{\text {st }}$ of Muharram celebration

If nganggung is a tradition of bringing and sharing food, one of the occasions where it is carried out is during the $1^{\text {st }}$ of Muharram celebration. Uniquely, such celebration is performed in all regions in Indonesia in different ways. The people of Bangka, for example, celebrate the $1^{\text {st }}$ of Muharram in a village called Kenanga village, although there are those who celebrate it in their respective areas. The tradition of celebrating $1^{\text {st }}$ of Muharram in Kenanga Village, Sungailiat district, Bangka Regency, has been going on for a long time. There is no historical record about the time it was originally celebrated. The results of interviews with several sources could not confirm when this tradition began.

During the $1^{\text {st }}$ of Muharram celebration, the people come to the mosque in the morning carrying a dulang (a place to carry food) covered with food cover. Here, various snacks such ketupat, rendang, stew meat and others are placed in the dulang.

The practice of bringing one pan from one house is called Sepintu Sedulang or nganggung. This practice shows the strong mutual help among the people of Kenanga in particular and the people of Bangka in general. All the food served on the pan will be eaten together. Rusydi Sulaiman, a humanist, academician, and community leader of Bangka said:

"The $1^{\text {st }}$ of Muharram is a religious celebration exceeding the crowds during Eid al-Fitr and Eid al-Adha celebrations. Besides the existence of nganggung carried out at the mosque, an open house is also held in each resident's house. They open the door all day long to welcome guests who come together from the neighboring villages and even outside the province. These guests come and take advantage of this moment once a year." 
The $1^{\text {st }}$ of Muharram tradition has been used as an agenda at the provincial level. Here, the budget from the Regional Revenue and Expenditure Budget is allocated on this tradition. At this moment, the national level speakers are invited to deliver tausiah (giving advice). The people and public figures from all groups gather. Therefore, an informant mentions the commemoration of the $1^{\text {st }}$ of Muharram is joyful and attended by all people, including those have different religions. Christians, Catholics, Buddhists, Hindus, and Confucians also attend the gathering by visiting the house of their acquaintances and enjoying the food they serve.

c. The Celebration of the Prophet's Birthday

The celebration of the Prophet Muhammad's birthday in Bangka mainly takes place in Kemuja Village, West Mendo District, Bangka Regency. During this celebration, people from all over Bangka Island come to the village and gather in crowd to have courtesy visit and the people of Kemuja hold an open house. In the morning, the people say a prayer jointly at the village mosque, and the Nganggung tradition is held.

This celebration is usually organized with several events. In 2017, for example, such celebration was linked to the Islamic Cultural Arts Festival and the Bangka Belitung Malay Festival. Both festivals welcomed the winners of the art competition to come on an open stage taking place on the Kemuja village soccer field and attended by the local residents and Bangka Regency and Bangka Belitung Islands Province officials.

In addition, an exhibition of old photos related to art and culture was also held, there were also photos depicting Sokarno's whereabouts, the first President of the Republic of Indonesia, when he was exiled in Bangka and various other historical photos that occurred in Bangka Belitung.

All informants have admitted the celebration of the Prophet's Birthday exceeds the crowds of Eid al-Fitr and Eid al-Adha celebrations. According to KH Hijazi Djama'in, the leader of the Al-Islam Islamic Boarding School in Kemuja, the people prepare meals for guests more than usual. He said,

"They have prepared a lot of chickens, for example, and the number is even more than usual, even up to 40 chickens. This is to welcome guests who come from different regions. They arrive in groups, with family or friends. They are not only from Bangka, but also other areas outside. In addition, they also have different religious backgrounds. Not only Muslims, non-Muslims also attend the open house."

\section{d. Sembahyang Rebut}

Besides the $1^{\text {st }}$ of Muharram celebration and the celebration of the Prophet's birthday where inter-ethnic and inter-religious communities encounter, the Chinese People of Bangka also have a celebration involving communities from different religions. One of the celebrations is Sembahyang Rebut.

The Chinese culture recognizes three main prayers, Kho ngian (Imlek), Chin Min (Cheng Beng), and Chiong Si Ku (Rebut). In every $15^{\text {th }}$ of the $7^{\text {th }}$ month in the Chinese calendar, the Chinese people perform Chit Ngiat Pan (a prayer carried out in the middle of the seventh month in the Chinese New Year) or Sembahyang Rebut (Chiong Shi Ku). They believe the door to the afterlife is open during this day (Khoi Kui Mun).

All spirits will come down to earth from the beginning of the seventh month. Among the spirits, there are those who roam or stray in an abandoned state. They desperately need food offerings. These abandoned spirits exist because they did not have children, died 
unnaturally, and died for a long time. Sadly, their generations or descendants do not know them and make offerings.

Several places in Indonesia are familiar with Chiong Si Ku prayer. Buddhists call this prayer the Ulambana celebration. In the meantime, Confucians know it as Jing Hao Peng Prayer (general spirits). Taoist teachings call it as a Tionggoan celebration (Zhong Yuan). Interestingly, such prayer is famous for Yu Lan Hui (Chinese Spirit Day) in Sarawak and the Ghost Festival (Gui Jie) by the international community, respectively. During this celebration, various offerings are made, including tubers, nuts, vegetables and fruit and put before the Thai Se Ja altar. The offerings are served for the spirits before returning to the afterlife.

The celebration preparation usually takes time and costs a lot. The Thai Se Ja statue which is designed look bigger and taller symbolizes the prosperity of the local environment. The statue is made of cloth or paper of five colors (blue, green, red, yellow and orange). Bamboos are used as the structure of the statue. An umbrella and protection flag is attached to Thai Se Ja's shoulders. The word Lin or Liang written on the flag means potent. Meanwhile, the umbrella that adorns Thai Tse Ja's shoulders known as the "Payung Kramat/sacred umbrella" becomes one of the auction items. It is believed to bring prosperity and protection. The auction funds go to the Pagoda treasury.

The peak of the Sembahyang Rebut is marked by the opening of red cloth or paper covering the eyes of the statue. This ritual is known as Khoi Kong. A hope for goodness is reflected in the writing on Thai Tse Ja's chest, Hap Ka (Ham Cung) Phin On - the Prosperity for all Citizens. The offerings at the Thai Tse Ja altar will be scrambled by the people. Everyone must get, even a grain of rice.

The Rebut ritual is held at midnight, at 00.00 WIB. After a sign is given, the people fight over to put their offerings at the altar. This is what makes this ritual known as Sembahyang Rebut (scrambling prayer). This is where all the people who are present, not only Chinese citizens, but also Malays and others, Confucians and Muslim, compete one another to get the offerings. Almost all informants agree to this, including Prof. Dr. Bustami Rahman. He said:

"I am a Chinese descent on my mother's side. So, Chinese culture is nothing new for me. Here, Chinese and Malay have been mingling for a very long time, like hundreds of years ago. In the Sembahyang Rebut ritual, for example, all communities are involved. As a child, I also fought over the food during the celebration. That has been a common thing, until now."

\section{The Role of Social Media in Moderating Religious Communities}

Ahmadi Sofyan, a cultural observer who ran for a member of People's Representative Council of Indonesia last year, claims the social media does not really bring a significant influence in Bangka as most of the conflicts can amicably be resolved trough familial bond. The People of Bangka has a culture known as "Ndak Kawa Nyusah", meaning they do not want to get into a trouble and do not want to interfere. To this end, their relationship leads to the idea of respecting one another and not prying on someone else's business. A conflict in a certain area, for instance, does not cause other religions in other regions to interfere, let alone be emotional, even though they come from different religious backgrounds. In short, a conflict in one area becomes the problem for the people in the area. Here, another area does not need to take a part.

However, although the social media has not played a significant role, just yet, some indications have been identified and detected. This is in line with the one mentioned by Sayyid Deqy, the author of Korpus Mapur dalam Islamisasi di Bangka. He claims his friends who are actively involved on social media have experienced some intimidation from the Islamic 
Defenders Front due to their posts on Facebook. The posts are deemed offensive to this movement. However, such issue does not lead to social conflict.

In fact, the thing to worry about, as stated by Bustami Rahman, is the current political system which prioritizes the power of money. It has the potential to cause major conflicts in society. Here, the political leadership is determined by the power of money. Those who are financially powerful are the ones who come forward to represent or lead the region.

"This political system will have an impact in the future. The minority that is economically powerful can control the majority. Consequently, it can easily cause social conflict. I'm worried that Bangka will experience it as the indications are starting to happen. Such political system is not healthy for the People of Bangka. Imagine, just because I was given a head scarf, a family member of mine was willing to vote a candidate who was probably not qualified."

Both issues, the social and political media, attract the attention of leaders, cultural observers, and religious leaders in Bangka.

As mentioned above, the research has discovered several interesting findings about the dynamics of moderation in Bangka Island. The existence of several conflicts that have happened in Bangka Island is inevitable. This is something that can be covered up and all informants mention the same thing. However, they claim the People of Bangka Island have enough approaches and strategies to maintain and build moderation although they come from different ethnic and religious backgrounds. The approaches and strategies include the followings:

1. Unifying Religious Tradition

The Chinese and the Malays consider they are equal and stand on the same direction. Muslims as the majority population do not discriminate against the minority. In the same way, the minority also opens up to the majority. The Islamic New Year, the Prophet's Birthday, and Rebo Kasan celebrations are proof of how Muslims are open to accepting anyone regardless of their ethnic and religious backgrounds. Each house conducts an open house for all guests without discrimination. Dishes are served and cooked more deliciously than usual. Indeed, it costs a lot of money. However, they are okay with it. Similarly, the minority, Chinese, for example, also involve Muslims and invite them to participate in celebrating the peak night of the Sembahyang Rebut ritual.

2. Adjoining Houses of Worship

As mentioned in the previous section, the houses of worship in Bangka Island are side by side. They were built adjoining one another. The mosque is next to the pagoda, the pagoda is side by side with the monastery, and so on. In addition, the process of constructing the houses of worship also involved different religious backgrounds, which is common in the island.

3. Government Support in Making Policy

The local government pays a great attention to building and keeping harmony among its people. It sees one of the essential things that can unite them is local traditions that have been rooted for a very long time. Therefore, it has made a policy and has even allocated funds on activities such as the celebration of Prophet's Birthday, the $1^{\text {st }}$ of Muharram celebration, and so on.

4. Excitingly, the celebrations involve the government, businessmen, customary leaders, religious leaders, and people in general. This means all elements of societies are involved and take a part in celebrating their togetherness in religious moments which are open for all parties. 
5. Jargons, such as Nda Kawa Nyusah, Fangin Tongin Jitjong or the Malays and Chinese are Equal, Sarumpun Sabalai, Sapintu Sadulang, and others are continuously promoted to protect the basic principles of society. By constantly instilling the values of these jargons, the people can always remind themselves that they are one regardless of their differences. They are members of the Bangka Island communities who have religious and cultural diversity, but are essentially one and inseparable.

Conflicts that have occurred are generally decided and solved based on deliberation and consensus. Unless a criminal element is involved. Here, such conflict will have legal procedures. However, the deliberation and consensus always takes precedence over others. This can be seen from the way the people solve the conflicts as illustrated in the previous section.

In short, these findings show the Bangka Archipelago has experienced an up-anddown regarding the harmony among its people. However, in general, the awareness of difference and the difference itself unifies the basic principles of the people of Bangka Island. This dynamic will continue to colour the island and nothing can stop it.

\section{CONCLUSION}

The people of Bangka have different cultural and religious backgrounds. The encounter of each background with one other has happened since hundreds or even thousands of years ago. Four pillars of harmony have been sustained and preserved in the life of the people in Bangka Island; religions with various rituals bring the people close together, political rulers make policies by referring to their different backgrounds, businessmen support the religious rituals, and customs in the way the customary leaders show their concern about maintaining the unity and integrity of the people of Bangka island. The meeting moments among people with different backgrounds are very important to maintain harmony and tolerance. The Islamic New Year, the Prophet's birthday, and Sembahyang Rebut celebrations are examples of local wisdoms which are carried out to maintain the harmony of the people.

Conflicts happen and they are inevitable. The conflicts here involve ethnic groups and religions. Some conflicts are decided and solved based on deliberation and consensus, but some take legal procedures due to the involvement of criminal elements. However, the conflicts show the existence of "ndak kawa nyusah (nothing to worry about)" has been rooted in the way everyone is given the opportunity to solve his/her own problems.

\section{Recommendations}

The government has an important role in building and maintaining the community moderation. For this reason, it must claim its role and clearly determine its position in society. The social media and political systems have the potential to change the harmony and moderation in the future. Therefore, the government and the people need to pay a bigger concern about these issues.

\section{References}

1. Fajrina Andini. Empat Tahun Lagi Penduduk Babel 1, 5 Juta Jiwa. 2016;(May 2016):2020-2.

2. Zulkii. Al-Islām al-mu'tadil wa thaqāfat Bangka Belitung: Al-Manūrāt al- 
Antrūbūlūjīah. Stud Islam. 2010;

3. Suparta S. Nilai-Nilai Pendidikan Islam dalam Budaya Nganggung dan Implikasinya Terhadap Solidaritas Umat di Kecamatan Mendo Barat Kabupaten Bangka.

MADANIA J Kaji Keislam. 2017;

4. Abimayu Y, Srinindiati D. SEJARAH TERBENTUKNYA KEPULAUAN BANGKA BELITUNG (PANGKAL PINANG) SEBAGAI SUMBER PEMBELARAN

SEJARAH. Kalpataru J Sej dan Pembelajaran Sej. 2020;

5. Sulaiman R. Dinamika Peradaban Kampung di Bangka. MAWA'IZH J DAKWAH DAN Pengemb Sos Kemanus. 2019;

6. Cholillah J. Orang Lom: Masalah Sosial dan Ancaman Kearifan Lokal dalam Tinjauan Sosiologi. Society. 2015;

7. Abdullah I dan B. Sejarah Sosial Cina Melayu. Yogyakarta: Tiara Wacana; 2011.

8. Gunawan IV, Kusbiantoro K. A Study of the Chinese Immigrants Housing Heritage at Gedong Village, Bangka Island - Indonesia. Am Int J Soc Sci. 2019;

9. Sayyid T. Korpus Mapur dalam Islamisasi Bangka. Yogyakarta: Penerbit Ombak; 2014.

10. Saidun D. Kapita Selekta Budaya Bangka. Bangka: Dinas Kebudayaan dan Pariwisata Kabupaten Bangka; 2016.

11. Sutrisno E. Aktualisasi Moderasi Beragama di Lembaga Pendidikan. J Bimas Islam [Internet]. 2019;12(1):323-48. Available from:

http://jurnalbimasislam.kemenag.go.id/index.php/jbi/article/view/113

12. Kartika S. Mutiara Negeri Melayu. Bangka: Media Center Press; 2019.

13. Elvian A. Dinas Kebudayaan, Pariwisata, Pemuda dan Olahraga Pangkalpinang. Pangkalpinang: Berfi Berjaya Mandiri.; 2015. 